\title{
Estudio filológico para una edición crítica de Horas y Fronda lírica, de Julio Flórez*
}

Fecha de recepción: 02 de agosto de 2016

Fecha de aprobación: 14 de septiembre de 2016

\section{Resumen}

Con el apoyo en los planteamientos teóricos de la Edición Crítica de Textos, en el método de la Nueva Filología y en las directrices lingüísticas de la Real Academia Española, se emprendió un recorrido ecdótico con miras a rescatar la obra completa del poeta colombiano Julio Flórez, desentrañar alteraciones en su proceso de transmisión editorial, depurarla, editarla e interpretarla. Algunos resultados de esa investigación mostraron inconsistencias lingüísticas y estéticas, es recurrente la introducción injustificada de variantes de tipo sustancial y accidental que, en su mayoría, alteran el sentido y el estilo poético, por ello se subsanaron en la elaboración de una edición crítica conformada por nueve libros de poesía, 120 poemas sueltos y uno inédito. En este artículo se presenta únicamente algunos comentarios sobre Horas (1893) y Fronda lírica (1908 y 1922), su tradición directa, la descripción y el análisis de variantes sustanciales y accidentales detectadas.

Palabras clave: edición crítica, variantes sustanciales, variantes accidentales, estilo poético, transmisión editorial, tradición directa.

Citar: Avendaño de Barón, G.S. (julio-diciembre de 2016). Estudio filológico para una edición crítica de Horas y Fronda lírica, de Julio Flórez. La Palabra, (29), 159-184. doi: http://dx.doi.org/10.19053/01218530.n29.2016.5708

\section{Gloria Smith}

Avendaño de Barón

Universidad Pedagógica y Tecnológica de Colombia, Colombia.glorieaesmid@gmail.com / gloria.avendano@uptc.edu.co. Doctora en Filología española. Docente del Doctorado en Lenguaje y Cultura y de la Maestría en Lingüística de la Universidad Pedagógica y Tecnológica de Colombia, Colombia; investigadora en el grupo GIESCAH, clasificado en categoría B por Colciencias, Colombia. Orcid. org/0000-0003-4969-8393.

* El artículo expone resultados parciales de una tesis doctoral intitulada Edición crítica de la obra completa del poeta colombiano Julio Flórez, sustentada en la Universidad Nacional de Educación a Distancia UNED- (Madrid, España). 


\section{la palabra}

\section{Philological Study for a Critical Edition of Horas [Hours] y Fronda lírica [Lyrical Foliage], by Julio Flórez}

\section{Abstract}

Based on the theory of Critical Text Editing, under the method of New Philology, and following the linguistic guidelines of the Real Academia Española, we embark on an ecdotic journey which aims at recovering the complete works of the Colombian poet Julio Florez, unveiling alterations in the editorial transmission process, in order to refine, edit and interpret this work. Some of the results of this research show linguistic and aesthetic inconsistencies: the introduction of unjustified substantial and accidental variations is common, altering the sense and poetic style of the work, which were necessary to ammend for the development of a critical edition formed by 9 books of poetry, 120 loose poems and one unpublished poem. This article presents a commentary of Horas [Hours] (1893) y Fronda lirica [Lyrical Foliage] (1908 and 1922) and their direct tradition, as well as a description and analysis of the substantial y accidental variations found in these two works.

Keywords: critical editing, substantial variations, accidental variations, poetic style, editorial transmission, direct tradition.

\section{Étude philologique pour une édition critique de Horas [Heures] et Fronda lírica [Ramure lyrique] de Julio Flórez}

\section{Résumé}

Nous avons réalisé une étude ecdotique pour récupérer les œuvres complètes du poète colombien Julio Flórez et déchiffrer de possibles modifications dans la pratique éditoriale de ses textes et établir, éditer et interpréter son œuvre. Nous avons pu mener à terme ce travail grâce à la théorie des Editions Critiques de Textes dans la méthode de la nouvelle philologie et des directrices linguistiques de la Royale Académie Espagnole. Certains résultats de cette recherche ont mis en évidence des inconsistances linguistiques et esthétiques. Nous avons repéré des variantes substantielles et accidentelles qui modifient le sens et le style poétique. On a corrigé ceci grâce à l'élaboration d'une édition critique composée de neuf livres de poésie, 120 poèmes détachés et un poème inédit. Dans cet article nous présentons quelques commentaires sur Horas (1893) et Fronda lírica (1908 y 1922), leur tradition directe et la description et analyse de variantes substantielles et accidentelles présentes dans ces deux textes.

Mots-clés: édition critique, variantes substantielles, variantes accidentelles, style poétique, pratique éditoriale, tradition directe. 


\section{Introducción}

El trabajo que se presenta aquí hace parte de una investigación mayor orientada a la elaboración de una Edición crítica de la obra completa del poeta colombiano Julio Flórez, cuyo propósito se centró en rescatar su producción poética, depurarla y fijarla de la manera más próxima a la que creó su autor, para asegurar la fiabilidad en procesos de interpretación, análisis, reflexión y valoración crítica. Pérez (2011) advierte que «para que sea posible la interpretación hay que partir primero del texto: el reconocimiento de la preeminencia de la letra y del espíritu del texto.» (p.16).

El acercamiento crítico al proceso editorial de la producción poética de Flórez estuvo motivado por el hecho de que durante el ejercicio docente en Educación Básica Secundaria, Media y Superior (desde 1986) se descubrió que en los libros destinados a la formación literaria en Colombia no se incluía a Flórez, estaba olvidado a pesar de haber sido coronado como Poeta Nacional de Colombia en 1923 por el presidente Miguel Antonio Caro, lo cual despertó curiosidad por conocer su obra. De igual manera, al emprender la búsqueda de su obra literaria se halló en la Biblioteca
Luis Ángel Arango de Bogotá lo siguiente: Julio Flórez Obra poética (1970), antología editada con el auspicio del Banco de la República; Julio Flórez en las letras nacionales y boyacenses (1997), compilación de poemas y comentarios sobre su obra, editada por la Academia Boyacense de Historia; y las obras Horas (1893), Manojo de Zarzas (1906), Cesta de lotos (1906) y Fronda lírica (1922) ${ }^{1}$. Una vez leída dicha documentación, se detectó que la escritura de muchos poemas editados posteriormente e incluidos en las dos antologías citadas no coincide con la de los textos tomados de sus originales, lo cual ameritó la preparación de una primera edición crítica que mostrara, de manera organiza$\mathrm{da}$, depurada y sin distorsiones de sentido, su obra completa. Es decir, se hacía necesaria una edición que permitiera rescatar la obra, aproximarla a la concepción primigenia de Flórez y difundirla para que fuera leída de manera confiable, interpretada y analizada críticamente por lectores contemporáneos interesados en este género literario.

El presente artículo da cuenta de una pequeña parte de esa investigación, la referida al aspecto filológico, cuyos objetivos se centran en revelar algunos comentarios sobre Horas y Fron- da lírica y su tradición editorial directa, mostrar y analizar las variantes sustanciales y accidentales introducidas sin justificación lingüística o estética durante los sucesivos procesos editoriales (Horas, desde 1912 hasta 1997 y Fronda lírica, desde 1908 hasta 1997). Se eligió como muestra este corpus, por cuanto las dos gozaron de gran receptividad en los lectores y porque presentan, con mayor ocurrencia, un infortunado proceso de adulteración en sus ediciones posteriores, debido, quizá, al capricho de los editores o al descuido, el irrespeto y la irresponsabilidad en las acciones de revisión, fijación y divulgación. Esto indiscutiblemente genera un gran cúmulo de variantes tanto deliberadas como involuntarias (por error) ${ }^{2}$ que obstaculizan la lectura del texto, atentan contra el estilo poético y el sentido propuesto desde su gestación y, por ende, empañan cualquier estudio crítico literario o de otra índole.

Julio Flórez representa el Romanticismo tardío que a finales del siglo XIX y principios del XX aún se mantenía en Colombia y en Hispanoamérica (Ocampo, 1997). Este movimiento apareció como una revolución artística contra el Neoclasicismo; se inició en Alemania en el siglo XVIII con

La obra príncipe, o primera edición, publicada por Julio Flórez en 1908 (en España) no se encontró en Colombia. Se entiende por variantes, las modificaciones intencionadas o las lecciones diferentes introducidas por equivocación del editor. 
poetas como Friedrich Schelegel y Johann W. Goethe y se extendió por Europa y el continente americano en los comienzos del siglo XIX. Sesto (1951) señala que el Romanticismo en el mundo se caracterizó por el culto al yo con exaltación de la propia personalidad, de ahí el predominio de lo subjetivo; libertad de imaginación y prevalencia del sentimiento en la creación poética; ansia de libertad en las ideas, la política y la moral; exclamación en el verso y frondosidad de palabras; plasticidad en la descripción; imposición de la irracionalidad sobre la razón; tendencia a vivir como se escribe. Esto generó en los poetas románticos un aspecto taciturno y compungido, pleno de imaginación y un modo de vida un tanto excéntrico; angustia de la existencia, sentir la vida como un problema insoluble; escepticismo e idea de lo infinito al que empujan anhelos vagos; espíritu idealista como aspiración a un mundo mejor; choque con la realidad del que sobreviene el desengaño y la huida hacia el pasado. Agregamos el predominio de temáticas como la frustración en el amor, la mujer, la muerte, la vida, la soledad, la melancolía, el recuerdo, el pesimismo, la aspiración al infinito (el más allá), la madre, la patria, el destierro, la naturaleza, la religión, la política, el infortunio y una mirada que buscaba trascender los límites y apariencias de las cosas.

En Colombia este movimiento literario halló circunstancias propias y adecuadas para su expresión, entre otras, los desdichados acontecimientos derivados de la Conquista, las historias ficcionalizadas de la Colonia, las hazañas asombrosas de la Independencia, las luchas ideológicas a raíz de la organización y construcción de una nueva república, y la exuberancia de sus paisajes tropicales.

Consideramos que la sensibilidad romántica de Flórez se forjó gracias a motivos como los siguientes. Recibió el influjo de dos grandes poetas románticos universales, de Víctor $\mathrm{Hugo}^{3}$ admiró la fuerza de sus sentimientos. Gómez (1940) refiere que a los 16 años Flórez compuso una oda a ese gran poeta francés y 12 años después la declamó en el teatro Colón de Bogotá; además, leía con frecuencia a Gustavo Adolfo Bécquer, poeta español esencialmente lírico. En 1881 inició sus estudios de Literatura en el Colegio Mayor de Nuestra Señora del
Rosario en Bogotá, pero tuvo que suspenderlos por la difícil situación económica por la que atravesaba su familia; esta infortunada circunstancia lo afectó emocionalmente.

Nació y vivió en un entorno convulsionado y violento, dadas las frecuentes disputas políticas entre los partidos que militaban en Colombia a finales del siglo XIX y comienzos del XX. Según Alvarado (1996), con la Guerra de los Mil Días (1899-1902) la nación quedó arrasada, la miseria pululaba por todas partes. Como no se sembraba, no había cosechas de ninguna clase; el comercio y los negocios estaban quebrados $\mathrm{y}$, por ello, mucha gente murió de hambre; un «soplo de muerte había permeado todo el país» (p. 9). Durante esta época apareció la Gruta Simbólica, que de acuerdo con Gloria Serpa-Flórez $(1994)^{4}$, era un grupo integrado por músicos y poetas unidos por el amor a la poesía, la bohemia irreverente, la oposición al sistema de gobierno imperante y los desplantes a la sociedad bogotana que desde distintas orillas tomaba partido en esa guerra fratricida. Las reuniones iniciaban a las ocho de la noche y, por el «toque de queda $\rangle^{5}$, se prolongaban hasta

\footnotetext{
Su padre fue asiduo lector de este escritor europeo, legado que le dejó a Julio y a sus dos hermanos también poetas. Julio Flórez fue el tío abuelo de Gloria Serpa -Flórez de Kolbe, quien aún vive.

En el año 1902, en medio de la Guerra, el presidente de Colombia José Manuel Marroquín decretó el «toque de queda», norma que prohibía salir a las calles en las horas de la noche, pero los integrantes de la Gruta simbólica la infringían y, de manera muy sigilosa, se reunían en la casa del médico Rafael Espinoza Guzmán y en algunas cafeterías ocultas en el centro de la ciudad, Bogotá.
} 
la madrugada del siguiente día. Flórez, quien militaba activamente con su poesía y su actitud en el movimiento político liberal, fue el líder de ese grupo de intelectuales que desafiaron a esa sociedad durante más de tres años y lograron distraer los rigores de la guerra civil que padecía el país. La Gruta simbólica se fue disolviendo en 1904 cuando asumió el gobierno de Colombia el General Rafael Reyes Prieto, de orientación conservadora, quien eliminó el «toque de queda» de manera que ya no era necesario permanecer en vela todas las noches. Sin embargo los comentarios en contra de su sistema de gobierno tuvieron efectos más rigurosos que pasar unos cuantos días en la cárcel; por ejemplo, Julio Flórez fue desterrado por su posición política.

Las anteriores circunstancias dejaron secuelas en Flórez que se manifestaron en actitudes de nostalgia, pesimismo, escepticismo, frustración, inconformismo, sentimiento de nacionalismo y rebeldía política, evidentes en varias de sus obras poéticas. Sirvan de ejemplo estas dos composiciones representativas de la tendencia romántica: en «Idilio eterno», incluida en Horas, se evoca la frustración que genera el amor imposible mediante la humanización del mar y de la luna, quienes enamorados, pero nostálgicos por su separación, dialogan en medio de la noche; $y$ en el poema suelto ¡Oh poetas!, se infiere una postura política contestataria, a través de un grito de protesta y de denuncia de la crisis socioeconómica, la violencia partidista y la represión que arrasaban a Colombia.

Max Grillo aseguró en la $R e$ vista Gris (septiembre de 1895) que Julio Flórez fue el poeta colombiano que mayor énfasis dio al pesimismo en sus poesías, tanto así que cualquier lector desprevenido al leer los versos de Gotas de ajenjo creía que su autor se había apoyado en el volumen las Fleurs du mal o en Leconte de Lisle. En palabras de Alvarado (1996):

Como Baudelaire, las gentes progresistas, los intelectuales liberales, los artesanos y vastos sectores sociales amaban más la muerte que la vida. La muerte, los cadáveres, las pestes, la miseria y un futuro hediondo a carroña eran los recuerdos y el presente de sus vidas. (p17).

A propósito, Sanín (1967) comenta que Flórez fue poeta de la muerte y de la nostalgia, «cultivó la tristeza como motivo de arte, le arrebató a ese estado de su espíritu notas altísimas de poesía viril, elocuente y armoniosa. Cantó amarguras de su vida, inutilidad de la existencia, amor filial e inanidad del esfuerzo» (p. 93). Algunos de los poemas de Flórez se convirtieron en canciones (boleros, baladas y pasillos) que se escuchaban por doquier; por ejemplo Flores negras y Gotas de ajenjo, cuyos versos pertenecen a la memoria colectiva de Colombia. Al respecto, Manuel Machado (citado por Panero, 1985) indicó:

La gloria de un poeta consiste en que el pueblo cante sus versos y los haga suyos porque entonces se han integrado al común, a lo que es de todos, al cuerpo y al alma totales de la patria, a su emoción tradicional, como invisible sangre generosa. (p. 22).

Este era el concepto de poeta que se tenía en la época: el insigne tejedor de la palabra que lograba la aceptación, la fama, el honor, la admiración, el elogio y el reconocimiento público de sus lectores al cantarle, por ejemplo, a temas como la frustración y el desengaño en el amor que están presentes en esas dos composiciones musicales.

No obstante, a principios del siglo XX se observó un viraje en el estilo poético de Flórez hacia el Modernismo, lo que puede ser atribuible al siguiente suceso. En 1907 el mismo presidente Rafael Reyes Prieto lo nombra como Segundo Secretario en la Embajada de Colombia en España, seguramente para mantenerlo aislado del país. Allí logró un buen posicionamiento en el 
mundo cultural de Madrid. Fue cofundador de la Revista Latina junto a Francisco Villaespesa y Amado Nervo. En compañía de otro diplomático colombiano, Alfredo Gómez Jaime, instauró pequeñas tertulias literarias, convertidas en veladas alegres que aglutinaban a lo más selecto de la intelectualidad española e hispanoamericana. Asistían, entre otros, Rubén Darío, Ramón del Valle-Inclán, Manuel Santos Chocano, Amado Nervo, Francisco Villaespesa, Manuel Machado, Carrere y Antonio Machado (Gloria Serpa-Flórez, 1994). Aquí Flórez publica su obra Fronda lírica (1908), donde sorprende con el poema «La araña» en el que muestra una significativa transformación estética, que acoge varias innovaciones del estilo modernista-simbolista ${ }^{6}$.

En «La araña», Flórez torna la mirada hacia la realidad exterior; abandona la rima y la métrica, y recurre a una araña de color negro como símbolo para explicar la visión de mundo, mediante imágenes sutiles $\mathrm{y}$ con musicalidad. El poeta busca impresionar a través del sentido de la vista: "con sus patas peludas/y su cabeza negra" (v.v.17 y 18); es decir, se describe la impresión que causa una araña negra y no la araña en sí misma. Este insecto, quizá, fue elegido por el poder creativo que se manifiesta en el hilar de su red, que simboliza el quehacer poético, el proceso tejedor de la palabra para expresar el pensamiento. Al respecto de este poema, Peña (1997) aduce que «el rasgo simbolista y la perfección estilística ubican a Flórez junto a obras universales como el "Nocturno", de José Asunción Silva; "Los camellos", de Guillermo Valencia o "El cuervo", de Edgar Allan Poe» (p. 62)7.

Ahora bien, el valor poético de Flórez se concreta en la espontaneidad con la que sabía interpretar las profundidades del alma popular y describir la naturaleza con emotividad, devoción y asombro para expresar sentimientos como el amor, el desamor, el nacionalismo y el arraigo patrio, y otras realidades como el ciclo del cosmos y el ciclo de la vida humana. $\mathrm{Si}$ bien por lo reducido de su léxico incurrió en repetición de algunas palabras en gran parte de su producción ("ósculo": beso; "la parca": la muerte), como también lo notó Henrí- quez (1967), el lenguaje estético de su poética contiene una estructura gramatical que está siempre al servicio del sentido que deriva la elección de las palabras y la organización interna de las frases y de las oraciones que constituyen los versos. El poder expresivo del lenguaje de Flórez se logra mediante el uso recurrente de adjetivos calificativos que hacen que lo descrito aparezca en la imaginación de quien interpreta como una realidad tangible, viva y perceptible por los sentidos físicos, pero portadora de un significado abstracto, velado, implícito. El uso de la metáfora logra la agudeza de las imágenes, la musicalidad poética y la capacidad para concebir desde su imaginación una realidad, un sentimiento, una idea. Valiosa y loable es también la capacidad de Flórez para superar lo denominado por Rivadeneira (1997) como el «desbocado anhelo de hermosura y de liberación que lo condujo a la ruptura del equilibrio estético, al extravío sentimental y a los excesos retóricos» ( $\mathrm{p}$. 48), para tornar a la mesura y a la discreción del ritmo cuando ingresa en la tendencia modernista-simbolista, a través del ya citado poema «La araña».

$6 \quad$ El modernismo se caracteriza porque intenta una reforma de estilo poético y busca un nuevo lenguaje, aleja el yo subjetivo y romántico, rastrea la inspiración en el mundo exterior, para lo cual toma como modelo el simbolismo y el parnasianismo. En el simbolismo, el lenguaje es el de la fantasía entretejida de símbolos, sus ritmos y sonoridades aparecen en el verso para enriquecer las imágenes sensoriales, se apoya en la descripción de las impresiones que causan las cosas y no las cosas mismas; se expresa a través de imágenes sutiles con musicalidad y colorido. El parnasianismo persigue una belleza estática, para ello crea una poesía descriptiva, inspirada en motivos griegos y en la mitología clásica (Estévez, 1999).

$7 \quad$ Esta apreciación coincide con la de R.J. Cuervo cuando recibe el primer ejemplar de Fronda lírica, lo cual se verá más adelante. 
Enseguida se presenta una breve fundamentación teórica, el método empleado en la investigación filológica que arrojó la elaboración de una Edición crítica de la obra completa de este poeta y resultados, en términos de exposición de algunos comentarios y tradición directa, descripción y análisis de variantes sustanciales y accidentales halladas en el proceso de transmisión editorial de Horas y de Fronda lírica.

Consideraciones generales sobre la Edición Crítica de Textos

Orduna (2005) define la Edición Crítica de Textos como una vertiente de la Filología que, desde los tiempos de los alejandrinos se centró en la edición de textos literarios y a lo largo de centurias de exégesis bíblica postuló, en el siglo XVIII, los fundamentos de la Crítica textual. Añade que Dom Quentin, preocupado por los problemas metodológicos que suscitó el proceso de edición crítica de textos, acuñó el nombre de $E c$ dótica para esta disciplina «que, al primitivo concepto de "arte", sumaba, destacándolo, el rigor científico de la metodología propuesta» (p. 17) ${ }^{8}$; sin embargo, independientemente de la línea metodológica adoptada en ese siglo, para cada editor estaba claro que su objetivo era la edición del texto; para lograrlo se adelantaba esta labor de manera sistemática, con gran cuidado y esmero por mejorar la versión disponible. La selección de los testimonios, el cotejo de las lecturas, la elección de las que debían integrar el texto por editar y toda la metodología utilizada se había concentrado, en últimas, en un criterio editorial aplicado a la nueva edición que mereció la denominación de crítica.

Pérez (2011) enfatiza en que el aporte de la Edición Crítica de Textos es indispensable y previo a la investigación literaria que quiera operar con algún rigor científico; por ello, antes de cualquier estudio crítico es conveniente partir de un texto rigurosamente fijado en su autenticidad. Insiste en que el objetivo de la Edición crítica de un texto es conocer los problemas que entraña la obra escrita en cuanto a su constitución y transmisión a través del tiempo, antes de abordarla como creación estética; por cuanto no será posible un estudio serio, si no se cuenta con un texto depurado y fiel a la intención de su autor. Por consiguiente, la tarea esencial del editor crítico es la de desentrañar y depurar las inconsistencias que plantea la obra en su nivel textual; por ejemplo: léxico (vocabulario, grafía, ortografía literal), acen- tuación, puntuación y estructura discursiva o poética. A este proceso se le denomina crítico porque el editor debe asumir una postura argumentada, desde lo lingüístico y lo estético (en el caso de la obra literaria), para evaluar el proceso escritural y editorial de las distintas ediciones objeto de la collatio 9 , tomar decisiones responsables e introducir las lecciones que permitan restablecer el texto, es decir, reconstruirlo y presentarlo de la manera más cercana y similar al original; sin embargo, cabe aclarar que el editor crítico también puede revisar, enmendar y mejorar la obra príncipe, generalmente autorizada por su autor. Continúa Pérez (2011) señalando que una edición crítica de una obra ofrece ayuda a la lectura y a la comprensión del sentido literal del texto, y advierte:

Quedarán sin duda muchos otros aspectos y valores de la obra por explicar. Pero eso será ya tarea propiamente de la crítica literaria. Nosotros, como filólogos y editores del texto, hemos contribuido a forjar los pilares sobre los que aquella edificará. Sin un texto establecido con rigor y sin una recta comprensión de su sentido literal, toda construcción crítica corre el riesgo de desmoronarse como un castillo de naipes (pp. 203-204).

\footnotetext{
8 Se entiende por ecdótica el proceso de edición crítica de un texto, o crítica textual.

$9 \quad$ La collatio es el cotejo del texto base con las ediciones elegidas para establecer la edición crítica de la obra.
} 
Pese a este planteamiento, considero que la edición crítica de una obra literaria debe ir más allá, debe trascender lo puramente literal para incursionar en procesos de interpretación, análisis y reflexión a partir de fundamentos epistemológicos y teóricos del campo del conocimiento que esté aludido explícita o implícitamente en ella. Es recomendable agregar en la presentación de una edición crítica de una obra literaria, un capítulo que muestre ese otro tipo de lectura $^{10}$.

Proceso de transmisión del texto

Siguiendo con Pérez (2011), las obras literarias del pasado que han tenido que sortear los múltiples avatares del transcurrir del tiempo, casi nunca llegan al presente tal como salieron de las manos de sus autores, y precisa lo siguiente:

El texto que conocemos como resultado, como dato, pocas veces nos ofrece las suficientes garantías de fidelidad y autenticidad. Se hace entonces necesaria una tarea que, con exigencias científicas de rigor y precisión, permita remontarse hacia atrás y conocer del modo más aproximado posible el proceso recorrido en la transmisión del texto, con el fin de llegar a la que hubo de ser la versión primigenia (p. 47).

Es decir, la mayoría de los libros de literatura antiguos han sido reeditados muchas veces por distintas editoriales, y esta práctica conlleva un alto riesgo de introducción, voluntaria o involuntaria, de modificaciones de contenido o de forma escritural que van deturpando su sentido y su calidad estética.

Este filólogo español indica que para hablar de ese proceso de transmisión es pertinente referir los siguientes aspectos fundamentales: en el génesis de todo está la existencia de un original y de unas copias del mismo a través de las cuales llega a los lectores; tal situación es la que determina y configura el proceso casi siempre complejo de transmisión de la obra. Así que, el primer concepto que surge es el de original o texto auténtico que plasma y revela la voluntad expresa de su autor; cuando está escrito con su propia mano se llama autógrafo (o manuscrito) y si está únicamente supervisado por él, pero no físicamente escrito, idiógrafo. En el caso de ediciones impresas, comúnmente se alude a edición príncipe, o primera edición. A la primera copia tomada del original, se le da el nombre de apógrafo y a la copia de la que a su vez se ha extraído alguna otra, antígrafo.

Muchas veces ocurre que se pierde el original y se conservan solo alguna o algunas copias manuscritas o impresas, a cada una de ellas se les denomina testimonio, puesto que, efectivamente, se convierten en un testigo del texto extraviado, además, porque ante ellas el editor asume el rol de juez que las interroga en aras de reconstruir la verdad, o la autenticidad del texto original; el conjunto de los testimonios conforma lo que se denomina la tradición de la obra, que puede ser directa o indirecta; la directa es la que forman todos los testimonios en sí mismos, y la indirecta está constituida por los de segunda mano referidos a la obra (glosas, traducciones, citas, comentarios críticos, resúmenes). El término lección significa una palabra, un pasaje o lugar específico del texto que es transmitido por alguno de los testimonios.

Generalmente, en cada edición que aparece se van introduciendo nuevas modificaciones, es decir, su cantidad aumenta progresivamente. Es oportuno indicar que no existen ediciones perfectas, pues son múltiples los factores que inciden en el momento de la escritura, o fijación del texto. Sin embargo, muchos de los cambios introducidos al texto original no son

\footnotetext{
10 En la Edición crítica de la obra completa del poeta colombiano Julio Flórez se incluyó un capítulo intitulado «La lectura del texto: "El adjetivo calificativo en la obra poética de Julio Flórez: análisis morfológico, sintáctico y semántico"».
} 
errores manifiestos, pues aparecen camuflados en el contexto configurando perfecto sentido, de tal suerte que pueden pasar por lecciones originales; en este caso, se hace referencia a las variantes lingüísticas sustanciales y accidentales: las sustanciales ponen en juego el sentido o la esencia de la expresión originaria, generalmente son de tipo léxico, y las accidentales, o de forma, tienen que ver, por ejemplo, con diferencias gráficas y fonéticas para una misma palabra, con aspectos ortotipográficos, acentuación, puntuación, división de palabras, digitalización, organización de estrofas, de versos, de párrafos, de capítulos, de partes. Se advierte que tampoco el texto apógrafo (primera copia del original) está exento de errores de autor, tanto de tipo sustancial como accidental. Existen también las variantes de autor que ocurren cuando él introduce deliberadamente modificaciones en su texto del que ya se ha extraído copias, cuando corrige en una nueva fase escritural o edición posterior.

\section{Método filológico}

De acuerdo con Orduna (2005), en el siglo XIX el filólogo alemán Karl Lachmann renovó profundamente el método de la reconstrucción de textos, o de edición crítica de textos an- tiguos, y sentó las bases de un nuevo procedimiento fundamentado en tres operaciones esenciales: Recensio, recogida de todos los testimonios de la tradición de un texto mediante su confrontación y la determinación de las relaciones existentes entre ellos, con el fin de configurar el árbol genealógico de los testimonios y establecer la hipótesis sobre la existencia de un arquetipo, esto es, el ascendiente más próximo al original perdido y del que han derivado los testimonios que se conocen. Emendatio, reconstrucción del arquetipo a través de la corrección de errores y la selección de variantes. Constitutio textus, paso del arquetipo al probable original, a lo cual se procede mediante la divinatio, o última y cuidadosa fase de restauración del texto apoyada en el usus scribendi (tomando en cuenta las características particulares de la lengua y el estilo del autor) y en el iudicium del editor (o por decisión razonada de quien elabora la edición crítica). Este método fue mejorado posteriormente por otros filólogos como Dom Henri Quentin y Paul Maas, pero refutado totalmente por Joseph Bédier, quien propuso el apoyo en un solo manuscrito para depurar únicamente los errores evidentes, esta postura fue duramente objetada por Alexandre Micha, cuyo planteamiento impedía la mera transcripción de un único manuscrito, por cuanto así se legitimaría el trabajo del copista y no la obra del autor.

A partir de 1930 surge en Italia un grupo de nuevos filólogos, entre ellos, Giorgio Pasquali, quienes trataron de introducir cambios a la rigidez metodológica imperante rompiendo el dogmatismo de Lachmann y el simplismo de Bédier. La nueva propuesta se centró en la combinación del rigor estemático (conformación, mediante la recensio, de un árbol genealógico de los testimonios hallados) con el estudio de la tradición textual de la obra que se pretende editar y de los problemas particulares. Los testimonios de esa tradición deben ser analizados y valorados individualmente, como producto que son de un determinado contexto cultural, y no solo como portadores de errores y modificaciones en su proceso escritural. Para la elaboración de la edición crítica de la obra de Flórez se adoptó este método de la Nueva Filología atendiendo a las siguientes fases recomendadas por Blecua (2012) y Estévez (1999) ${ }^{11}$ :

La recensio consistió en la búsqueda en distintas bibliotecas de Colombia y en la Casa Museo Julio Flórez ${ }^{12}$ de todas sus

11 En este apartado se da cuenta, de modo sintetizado, del procedimiento seguido para elaborar la Edición crítica de la obra completa del poeta colombiano Julio Flórez; puesto que es pertinente indicar el contexto general del proceso investigativo que permitió el logro de lo que en este artículo se presenta. 
obras publicadas, sus ediciones posteriores, antologías, libros biográficos y comentarios sobre esa producción poética. Esta exhaustiva indagación arrojó la siguiente documentación: ocho obras publicadas en vida del poeta; una póstuma; 120 poemas sueltos divulgados en periódicos y en revistas nacionales e internacionales; un poema inédito autógrafo ${ }^{13} ; 11$ poemas en manuscrito (ya publicados), tomados de un cuaderno de apuntes fechado de 1901; y 18 antologías. Para una mejor identificación, a cada uno de los documentos se le asignó un código (a modo de sigla).

Esta revisión documental fue esencial en el proceso investigativo, toda vez que su lectura permitió conocer en profundidad la vida del poeta, su obra completa, las distintas interpretaciones y los comentarios recibidos en su época, que, a propósito, respondían solo a una lectura intuitiva, a las impresiones que cada poema suscitaba; es decir, se abordaba el texto li- terario desde la sensibilidad del lector; las lecturas de la obra de Flórez no alcanzaron el nivel analítico, no es posible considerarlas como estudios críticos elaborados rigurosamente desde una fundamentación teórica y epistemológica, pero hoy se podría incursionar en investigaciones más profundas y científicas centradas en la crítica literaria de su obra.

Abordado este proceso de recolección, lectura, análisis y evaluación de la información hallada, se seleccionaron las ediciones que sirvieron para la collatio; por ejemplo: para $\mathrm{Ho}$ ras se tomó como texto base el apógrafo, 1893 (AP) y el cotejo se practicó con tres ediciones posteriores: Julio Flórez. Poesía (1945), Biblioteca Popular de Cultura Colombiana, Ministerio de Educación Nacional de Colombia (MEN); Julio Flórez. Sus mejores poesías, antología (1951), México (ElibrES) y $J u$ lio Flórez. Obra poética (1970), Publicaciones del Banco de la República, editorial Minerva,
Bogotá (MI). Para Fronda lírica sirvió como texto base el apógrafo de la 2. ${ }^{\text {a }}$ Edición, 1922 (AP) y el cotejo se realizó con dos ediciones posteriores: Julio Flórez. Poesías (1931), Casa Editorial Sopena, Barcelona (SO); Julio Flórez. Antología poética (1985), Círculo de Lectores, Bogotá $(\mathrm{CdL})^{14}$, y con los siete manuscritos hallados ${ }^{15}$.

En la constitutio textus se configuró el texto de cada una de las obras con base en la emendatio (corrección de los errores que reveló el cotejo de las ediciones) y en la selectio (escogencia de las lecciones eliminando las no acogidas). Se recurrió a enmiendas conjeturales, ya que fue necesario adoptar criterios substitutorios; por ejemplo, el usus scribendi, o la selección de la lección que mejor se ajustara al estilo del Flórez y al sentido del poema ${ }^{16}$. En notas de pie de página se fundamentó, desde el punto de vista lingüístico o estético, el rechazo y la elección de las variantes sustanciales y de las accidentales introduci-

12 La casa en donde murió el poeta está ubicada Usiacurí, Atlántico, Colombia; se convirtió en un museo por solicitud expresa de sus hijos, allí reposan su tumba y algunos objetos personales; mobiliario; tres obras (textos apógrafos); textos manuscritos autógrafos de sus hijas; un cuaderno que contiene poemas manuscritos autógrafos del poeta; dos poemas manuscritos autógrafos en hojas sueltas; fotografías; cuadros de decoración; obsequios recibidos; la corona de laurel concedida por el gobierno nacional y muchos álbumes con un buen número de recortes de prensa en donde aparecen publicados algunos de sus poemas y diversos comentarios de su obra, escritos por presidentes de la República de Colombia, gobernantes extranjeros, periodistas y literatos nacionales e internacionales.

13 Hallado en manuscrito en la Casa Museo Julio Flórez.

14 El criterio de selección de las ediciones posteriores de las dos obras se apoyó básicamente en su completitud.

15 «Altas ternuras», «La voz del río [Balada del Río]», «Marta», «Fin de un drama», «El rey Febo [Febo]», «Nina» y «Buscadores de orquídeas».

16 La lectura y relectura de la obra completa permitió detectar el estilo poético de Flórez: su léxico preferido y reiterativo, la métrica, la versificación, la rima, la adjetivación restrictiva y la no restrictiva, el uso particular de la diéresis y de los apóstrofos, el manejo de la puntuación (signos de admiración y de interrogación retórica sin apertura, comillas, uso recurrente de puntos suspensivos), entre otros aspectos de expresión estética. 
das. Cabe advertir que el criterio de edición fue respetuoso del texto base que sirvió para el cotejo, pero sin dejar de intervenir para modernizar la ortografía literal y la acentual y para subsanar las inconsistencias de edición que alteraran el sentido y el estilo poético. Esta segunda fase metodológica centró la atención solamente en el proceso de corrección de anomalías $\mathrm{y}$ de selección de las lecciones que debían ser acogidas.

La dispositio textus se concretó con el establecimiento, o fijación, de los poemas; se numeraron los versos con los que inicia cada estrofa. Se incluyó el aparato crítico de notas textuales, conformado por la relación de las variantes sustanciales y las accidentales no acogidas en el texto, y el aparato de notas explicativas. Se optó ubicar el primero hacia el margen derecho, de esta manera: a la derecha del verso respectivo aparecen el texto base, si es el caso, y/o el testimonio, o los testimonios, de la collatio separados por una coma, y el último de ellos va precedido de dos puntos para registrar la variante, o la lección no acogida; los códigos de identificación de los testimonios se registran a la izquierda de la variante $^{17}$. El aparato de notas explicativas se ubicó en pie de página, contiene aclaraciones, precisiones, explicaciones lingüísticas o estéticas por las cuales se rechazó una lección y se eligió otra, interpretaciones y especificación de pasajes o lugares del texto en los que se detectó alguna alusión de tipo cultural, histórico, social o geográfico que debía ser precisada. Ahora aparece un ejemplo de la forma como se fijaron los distintos poemas que constituyen la edición crítica de la obra completa de Flórez (poema «Mediodía», de Horas):

\section{MEDIODÍA ${ }^{\mathrm{a}}$}

Deslumbra el sol en la mitad del cielo;

mares de luz desde el cenit envía, $\mathrm{y}$ ante su rayo abrasador, el hielo

se torna en llanto en la montaña umbría.

5 Es hora del trabajo; en las ciudades recomienzan los hombres sus tareas; y el humo entre infinitas claridades brota de las negruzcas chimeneas.

9 En los lagos las náyades a solas, flotan cual sobre piélagos de llamas, y los peces ostentan en las olas el oro y el azul de sus escamas.

17 Esta ubicación del aparato crítico de notas textuales permite confrontar con facilidad las variantes acogidas e incorporadas al texto con las desechadas.

a El título aparece en el AP en forma separada «MEDIO DÍA», aquí lo registramos como lo presenta el Diccionario panhispánico de dudas (2005, p. 429): «mediodía», para referir 'Momento en que está el sol en el punto más alto de su elevación sobre el horizonte'; en esta misma forma lo establecen ElibrES y MEN. «MEDIODÍA» ha sido considerado por la crítica literaria como uno de los mejores poemas de Flórez. A través de una expresión pictórica, devela una «exuberancia de lozano frescor, de ricos matices y de virgen savia» (Ponce, 1893). 
13 Óyese el rudo golpe del martillo sobre el ascua que cruje y que se queja; y en los prados la voz del caramillo ${ }^{\mathrm{b}}$ hace dúo ${ }^{c}$ al balido de la oveja.

MEN: camarillo AP: duo

17 Arde la tierra; el ave se guarece bajo las verdes y tupidas frondas, ${ }^{\mathrm{d}}$

MEN: frondas; el trigal brilla y ante el sol parece sordo huracán ${ }^{\mathrm{e}}$ de cabelleras blondas.

21 Hunde el gañán la deslumbrante azada ${ }^{\mathrm{f}}$ en el surco que el rojo sol caldea, en tanto que $\mathrm{a}^{\mathrm{g}}$ su frente retostada de sus cabellos el sudor gotea.

25 La brisa abochornada finge amores y se aquieta y se esconde en los pensiles; se oyen besos de aromas en las flores y rugidos de amor en los cubiles.

29 Besa una flor la abeja: el delicioso néctar la flor le da con embeleso, y la abeja borracha y sin reposo va en busca de otra flor y de otro beso.

33 Es hora del calor; vagos efluvios ElibrES: es la hora de lujuria dan brío a las faenas;

MEN, ElibrES: que en su frente

b «caramillo» denota 'flauta pequeña de caña, madera o hueso, con sonido muy agudo' (Diccionario esencial, 2006, p. 277); no obstante, su sentido poético alude al canto de un pájaro. La variante sustancial que introduce MEN, "camarillo», carece de significado, al menos, denotativo; se incurre en una deformación del vocablo por metátesis, o cambio de lugar de un fonema en el interior de palabra.

c En el AP no aparece el acento ortográfico en * «duo», debe llevarlo, puesto que dicho vocablo contiene hiato, la vocal alta /u/ está en contacto con una vocal media /o/; por ello, el acento de intensidad recae sobre la vocal cerrada. Este recurso lingüístico incrementa el número de sílabas del verso, lo que permite mantener el isosilabismo que caracteriza al poema.

d Se observa en este verso, y en muchos de otras obras de Flórez, el empleo de la adjetivación coordinada copulativa: verdes y tupidas frondas; según la Nueva gramática de la lengua española (2009), la constituyen dos adjetivos unidos por una conjunción coordinante; es decir, a un mismo nombre se le asignan dos propiedades. Con este recurso lingüístico-estético, el poeta describe, mediante una apropiada combinación de adjetivos, la espesura y la lozanía del bosque, único refugio que encuentran las aves para huir del sol y del calor abrasante en la hora meridiana.

e La imagen poética «el trigal brilla y ante el sol parece/ sordo huracán de cabelleras blondas» contiene un epíteto surrealista (Sobejano, 1970): la expresión sordo huracán es portadora de una imagen cualitativa, incoherente en cuanto al significado referencial del sustantivo al que se une; en el poema permite describir la belleza, la fuerza, el impacto visual y el ímpetu, aunque silencioso, de las espigas doradas por el sol canicular.

f En esta estrofa, Flórez alterna dos adjetivaciones no restrictivas (deslumbrante azada, rojo sol) con una adjetivación de tipo restrictivo (frente retostada); este recurso estético, frecuente en toda la producción poética de Flórez, le confiere musicalidad y ritmo a los versos que describen la potencia del sol meridional sobre el labriego que con esfuerzo cultiva la tierra. La estrofa en su conjunto exalta la laboriosidad del campesino y la posibilidad de generar vida en el contexto de un clima tropical.

g Las ediciones MEN y ElibrES cambian la preposición -a por -en, sin justificación alguna, con esta decisión incurren en la alteración del sentido de la estrofa. 
la luz arde en los cielos en diluvios, $\mathrm{y}$ en diluvios de fuego arden las venas.

37 Ansias incomprensibles se desbordan de los vírgenes senos; flotan mares de luz en las pupilas, y se asordan en el fondo del alma los pesares.

41 Bullen las savias; los retoños nuevos ${ }^{\mathrm{h}}$ revientan en las vírgenes montañas; AP: virgenes se estremecen las aves en los huevos... Y sacuden los fetos las entrañas.

45 Las fieras en sus hórridas guaridas ${ }^{\mathrm{i}}$ los músculos se oprimen temblorosas, y se lamen las jetas sonreídas y se palpan las garras espantosas.

49 El turbulento y platëado ${ }^{j}$ río hierve y levanta sus convulsas olas, y aunque azota las márgenes, bravío, por besarlo se inclinan las corolas.

53 En el desierto el caminante busca el oasis que brinda sombra y calma, mientras que el sol canicular chamusca las polvorientas hojas de la palma.

57 Los amantes se ocultan en la sombra de los frondosos árboles, y luego... AP: luégo... se recuestan del césped en la alfombra, y hacen vibrar sus ósculos de fuego.

h La arquitectura estética de esta estrofa está anclada sobre un lenguaje musical, vigoroso y estridente por el predominio de dos fonemas vibrantes: /rr/, múltiple, alveolar sonoro (retoños, revientan) y $/ \mathrm{r} /$, simple, alveolar sonoro (vírgenes, estremecen, entrañas). Alternando la adjetivación restrictiva -retoños nuevos- con la no restrictiva -vírgenes montañas-, Flórez describe el milagro de la fertilidad, de la procreación, de la reproducción de la naturaleza gracias a la intensidad del calor que irradia el sol, o el rey Febo, como lo denomina en su obra Fronda Lírica (1922).

i En esta estrofa, el poeta juega con la lengua alternando una adjetivación no restrictiva (hórridas guaridas) con dos restrictivas (jetas sonreídas, garras espantosas), para describir el vigor, la pasión y el erotismo que las horas centrales de un día caluroso suscitan hasta en la fauna. El adjetivo calificativo hórridas está construido mediante un proceso morfológico de derivación, su innegable sonoridad, otorgada por el fonema vibrante múltiple / $\mathrm{rr} /$, ahonda el efecto semántico referido al rasgo salvaje y viril de esa especie animal. Al igual que en la estrofa anterior, Flórez construye el sentido a través de la fuerza y de la sonoridad del lenguaje que propician la recurrencia y la combinación de las consonantes vibrantes a lo largo de los cuatro versos que la componen: fieras, hórridas, guaridas, oprimen, temblorosas, sonreídas, garras. Se observa el modo como Flórez interpreta la naturaleza a través de un prodigioso derroche de imágenes en su poesía descriptiva.

j El poeta marca diéresis a la vocal media, anterior, palatal /e/ a fin de mantener el isosilabismo del poema. 
60 Cómo brillas ¡oh sol esplendoroso!

no hay una nube que tu rayo

quiebre;

tú la vida difundes ¡oh coloso!

¡Pero avanza!...¡Natura tiene fiebre! ${ }^{18}$

De esta manera se estableció la obra completa del poeta evitando presentar una edición distanciada de los textos apógrafos. La reconstrucción del proceso de transmisión de su producción poética suministró variada información sobre la recepción, el estilo poético y la tradición editorial a través del tiempo, datos valiosos tanto para la propia edición crítica como para el abordaje de futuros estudios críticos de tipo literario, entre otros.

En el ámbito de los resultados de este estudio filológico, veamos algunas interpretaciones y comentarios, la tradición directa, la descripción y el análisis de las variantes sustanciales y accidentales detectadas en Horas y en Fronda lírica:

\section{Horas}

Este fue el primer libro de Julio Flórez, como se comentó ya, se publicó en el año 1893 , editado en Bogotá, Casa edito- rial J.J. Pérez. Su texto apógrafo (AP) reposa en la Biblioteca Luis Ángel Arango de Bogotá, Colombia, bajo la signatura «12780, Misc., sección Libros Antiguos y Raros». Está conformado por cuatro poemas: «Aurora», «Mediodía», «Ocaso y noche» e «Idilio eterno». Una vez recibida esta obra de manos de la editorial, Flórez envió un ejemplar a su hermano (encarcelado en Bogotá), con la siguiente dedicatoria: «Alejandro: no lo veo porque sufro horriblemente; perdóneme, algún día comprenderá mi alma. Crea en Dios. Julio, 1893» (Serpa, 1994, pp. 155-156).

En este mismo año, Ponce publica en la Revista Gris el artículo «Julio Flórez y sus "Horas"», allí expone sus impresiones personales a partir de los aciertos del poeta y aquello con lo que no estaba de acuerdo:

Flórez es poeta, y poeta verdadero, $[\ldots]$ porque no creo que haya quien le niegue dones tan excelsos como los que Dios y la naturaleza le han concedido para que vacíe en formas admirables el pensamiento que concibe. [...] Flórez me parece un poeta original, hasta donde cabe la relatividad del vocablo, de raro talento y de exquisito tacto para hacer de sus versos, por lo general, miniaturas de no poco valor artístico [...] En Horas, la musa del señor Flórez se presenta más bella que otras veces, más sana, si se me permite la expresión; y por eso me complazco con el poeta y le envío mi aplauso sincero. (1893, p.331)

Entre los comentarios infortunados, subraya: «Será un capricho mío, pero es cierto que me desazona eso de humanizar cosas tan admirables como la luna y el mar, para hacerles hablar como cualquier hijo de vecino» $(341)^{19}$. Ponce olvidaba que todo lo que existe en el universo es susceptible de poetizarse y la prosopopeya, o personificación, es un recurso estilístico acogido también por grandes exponentes de la literatura española e hispanoamericana; en palabras de Lapesa (1981): «Uno de los más bellos sueños de la poesía ha consistido en imaginar que la naturaleza está dotada de alma y que entre ella y los humanos se establecen corrientes de intercambio sentimental» (p. 40). Poetizar es darle vida con la palabra a todo lo que rodea al

18 Desde una perspectiva hermenéutica, consideramos que el poema «Mediodía» es una exaltación de la hora meridiana; connota un ciclo cósmico: el crecer, representado en el ascenso del sol hacia la cúspide, o posición central. El poeta recrea este período natural mediante la descripción de los efectos del astro rey, pues su fuerza invita al trabajo, al amor, al erotismo y a la pasión; acciones y sensaciones que constituyen el génesis de la vida. En síntesis, Julio Flórez, a través de esta composición poética, muestra la tricotomía indiscutible sol- fecundidad-vida.

19 Se refiere al poema «Idilio eterno» incluido también en Fronda Lírica. 
ser humano; es apalabrar lo que se siente, se piensa y se percibe a través de los sentidos físicos. Así que, al comparar esta segunda impresión de Ponce con la primera, es evidente una contradicción, ya que no se compadece con su apreciación inicial «Flórez es poeta, y poeta verdadero [...] para que vacíe en formas admirables el pensamiento que concibe». Restrepo (1972), por su parte, relata que el presidente de la República de Colombia, Miguel Antonio Caro, tan pronto recibió un ejemplar de Horas, le envió a Flórez este mensaje:

He leído algunas de las últimas poesías de Ud., en las que encuentro las más bellas formas de la lírica, animadas ya por el soplo de vida, por inspiración cristiana. Siga usted por esa senda luminosa: eso es ascender muy alto y ganar el primer puesto. Desde mi ocaso literario felicítolo. (p.17)

A este mensaje, y con sentimientos de gratitud y elogio, Julio Flórez le respondió: «Los genios como usted no tienen ocaso» (p.17). Martínez (1973) también destacó esta obra con el siguiente comentario: «En Horas [...] encontramos el sí- mil plástico y novedosísimo [...] no ya un símil aislado, sino una arquitectura completa de símiles, es decir, una alegoría». (p. 46). Seguramente Martínez se refería al conjunto de metáforas articuladas entre sí, a las que el poeta recurrió para simbolizar ideas abstractas a través de elementos concretos. En sus tres primeros poemas «Aurora», «Mediodía», «Ocaso y noche» se representa, con gran asombro, el ciclo cósmico nacer-crecer-morir-renacer, mediante una alabanza a los tres momentos cardinales del día, y el último, «Idilio eterno», como ya se comentó, mediante la personificación del mar y de la luna evoca la frustración que genera el amor imposible; se describe al mar como un monstruo rugiente, soberbio, viril, enamorado de la luna e impaciente por la ausencia de su amada, y a la luna, como un satélite natural, delicada, melancólica, ingenua y seducida por el mar. Véanse solo las estrofas 1,2 y $3^{20}$ :

Ruge el mar y se encrespa y se agiganta;

la luna, ave de luz, prepara el vuelo,

y en el momento en que la faz levanta, da un beso al mar y se remonta al cielo.
Y aquel monstruo indomable que respira tempestades y sube y baja y crece, al sentir aquel ósculo, suspira... y en su cárcel de rocas...se estremece!

Hace siglos de siglos que de lejos

tiemblan de amor en noches estivales:

Ella le da sus límpidos reflejos, Él le ofrece sus perlas y corales!

Ahora se expone la tradición directa de la obra primigenia de Flórez: en 1912, Horas apareció en la antología Harvard College Library, Estados Unidos; el 22 de mayo de 1915 se publicó en el periódico colombiano EL Liberal Ilustrado, tomo IV, número 1.368-16; varios años después, Ediciones La Gran Colombia (1943) la divulgó en su totalidad; Ediciones Académicas (1943), Barcelona, tomó en cuenta solo el poema «Idilio eterno». Las siguientes ediciones: Ministerio de Educación Nacional de Colombia (MEN 1945) ${ }^{21}$; El Libro Español (ElibrES 1951), México, y Minerva (MI 1970), Bogotá, incluyeron los cuatro poemas que la conforman; y el Instituto Colombiano de Cultura (1973) acogió solamente a «Idilio eterno».

20 Versión establecida en la Edición crítica (Avendaño, 2014). Los fragmentos de los poemas que aparecen en adelante son tomados de esta misma fuente.

21 Solamente se registra el código de las ediciones que se utilizaron para la collatio en el proceso de edición crítica de Horas y Fronda lírica. 
En Julio Flórez o la retórica del dolor (1982) de Jaime Mercado, Bogotá, aparece en forma completa; Ediciones Bedout (1983), Medellín, Colombia, incluyó «Idilio eterno» y «Aurora»; el Círculo de Lectores (CdL1985), Bogotá, incorporó toda la obra; en la colección Tiempo Presente (1990), Bogotá, se editó únicamente «Idilio eterno»; la Editorial Panamericana (1997), Bogotá, eligió «Aurora» e «Idilio eterno»; y la Academia Boyacense de Historia (1997), Tunja, Colombia, seleccionó «Idilio eterno».

En definitiva, Horas aparece editada, en forma completa o parcial, en los siguientes años: 1912, 1915, 1943, 1945, 1951, 1970, 1973, 1982, 1983, 1985, 1990 y 1997. En dicha tradición directa se observa que las ediciones que no la incluyeron en forma completa, sí prefirieron el poema «Idilio eterno», esto supone su valoración favorable.

En relación con el proceso de edición crítica de la producción de Flórez, conviene reiterar que el criterio fue respetuoso, especialmente, del texto apógrafo (AP), pero sin pasar por alto algunos casos de acentuación, normalización de grafías y ortografía (se aplicaron las novedades de la Ortografia de la lengua española, 2010). Se respetó siempre la diéresis que Flórez marca en vocablos como "ocëano" "rüidos" "bëoda", entre otros; esta es una licencia métrica propia del estilo del poeta, que permite aumentar una sílaba al verso y, con ello, conservar el isosilabismo del poema. El análisis filológico que se muestra aquí, se apoyó en las modificaciones halladas en la collatio y se presentan bajo la siguiente categorización: variantes sustanciales y variantes accidentales; como ya se informó, se eligió como texto base el apógrafo 1893 (AP), para cotejarlo con las ediciones Minerva 1970 (MI), Ministerio de Educación Nacional 1945 (MEN) y El Libro español 1951 (ElibrES). Obsérvese la descripción y el análisis de dichas variantes en Horas:

\section{Variantes sustanciales}

Las variantes sustanciales son generalmente de tipo léxico (palabras llenas y palabras de enlace) y siempre afectan al sentido del texto. Veamos algunos casos: en «Aurora», v.21, ElibrES reemplaza "muge" por "ruge", estos dos verbos tienen sentidos diferentes, el segundo no es un sonido propio de un toro, pues la estrofa está describiendo la manera como ese animal saluda el amanecer de un nuevo día. En el v.38, las ediciones MEN y ElibrES cambian la lección "flébil" del AP por "débil", según el Diccionario esencial (p. 681), "flébil" significa 'triste', 'lamentable', pero en el contexto poético es un adjetivo que alude a los tímidos rayos del sol en los albores del día, que simbolizan el nacer.

En el poema «Mediodía», v.15, la edición MEN trastoca algunas sílabas del sustantivo "caramillo" y fija "camarillo", poéticamente el primero connota el canto de un pájaro; por tanto, la variante que introduce MEN carece de sentido en ese entorno, se incurre en una deformación del vocablo por metátesis, o cambio de lugar de un fonema en el interior de palabra. Sin justificación, en el v. 23 las ediciones MEN y ElibrES cambian la preposición $-a$ por $-e n$, así: eligen la expresión *“en su frente retostada" en lugar de "a su frente retostada" como aparece en el AP, puesto que así lo exige el verso que le sigue "de sus cabellos el sudor gotea", con esa decisión del editor se alteró el sentido de la estrofa.

En «Ocaso y noche», v.v. 34 y 35, ElibrEs cambia sin razón el adjetivo calificativo "blancas" por "blandas", escribe "[...] rosas/ frescas y blandas" en lugar de "[...] rosas/ frescas y blancas", este último fue el adjetivo elegido por el autor, y su pertinencia es evidente.

En «Idilio eterno», la edición MEN introduce una variante sustancial al cambiar el sustantivo "rastros", elegido por el AP, por "astros", v. 49, lo que genera incoherencia, toda vez que de acuerdo con el sentido 
del verso, el segundo es inapropiado por razones semánticas.

\section{Variantes accidentales}

Si bien este tipo de modificaciones tiene que ver con aspectos de forma (digitalización, grafía de las palabras, signos de puntuación, acentuación, ubicación de versos y de estrofas, métrica, rima y ritmo), también pueden tergiversar el sentido; obsérvense las siguientes muestras: en el poema «Mediodía», v. 33, ElibrES adiciona un artículo definido femenino al fijar "es la hora del calor", en lugar de "es hora del calor" como aparece en el AP, lo que rompe el ritmo de la estrofa. Es oportuno advertir que en la edición crítica de la obra completa de Flórez se intervino para modernizar lecciones o enmendar algunas anomalías detectadas en el AP, a saber: el título aparece en forma separada * «MEDIO DÍA», entonces, unimos estos dos vocablos tal como lo recomienda el Diccionario panhispánico de dudas, 'mediodía' (2005, p. 429). En el v.16, el AP no marca acento gráfico en la lección * "duo", como es un vocablo que contiene hiato, fenómeno lingüístico que ocurre cuando dos vocales seguidas dentro de una palabra pertenecen a sílabas distintas, en este caso, una vocal cerrada tónica $(-u)$ precedida de una abierta (-o), debe lle- varlo, además para preservar la unidad métrica del poema; por el contrario, en el v.58 eliminamos la tilde que el AP ubicó en el conector de secuencia *"luégo", por cuanto esta es una palabra llana terminada en vocal; y en el v. 42, tildamos la palabra "vírgenes", ya que según la Ortografía de la lengua española (2010, p. 232), todas las esdrújulas llevan tilde.

En «Aurora», v. 1, la apertura del signo de admiración no aparece en el AP, las ediciones MI, ElibrES y MEN lo introducen, atentando así contra ese estilo poético recurrente en todas las obras de Flórez y en algunas de poetas extranjeros de la épo$\mathrm{ca}^{22}$. En el v. 62, las ediciones MEN y ElibrES eliden la coma que el autor introdujo después de "efluvios" para encerrar un enunciado explicativo: "Y se eleva dorando los pensiles,/ que esparcen sus balsámicos efluvios,/ al descender sus rayos cual sutiles [...]"/, esta puntuación es necesaria para enfatizar el sentido. En esta misma estrofa ElibrES, v. 64, rompe la construcción adjetival restrictiva al introducir sin motivo una coma entre el sustantivo y el adjetivo: *"hebras, flotantes de cabellos rubios"/.

En «Ocaso y noche», v. 38, el AP marca diéresis sobre la vocal alta, posterior, velar/u/ que conforma el diptongo en la palabra "rüidos", a fin de convertirlo en hiato y así mantener el isosilabismo, pero ElibrES lo elimina sin razón. En el v.14, MEN y ElibrES suprimen el demostrativo femenino "esa", atentando así contra la unidad métrica que permea el poema.

Es necesario mencionar que en el AP de Horas sí se observa la preocupación de Flórez por unificar la técnica poética, mediante el uso del endecasílabo en todos los cuatro poemas que la componen, estilo que como ya se evidenció, no fue respetado en algunas ediciones posteriores; en cambio, la rima consonante que caracteriza a esta y a la mayoría de sus obras, sí se preservó.

Sintetizando, en Horas son notorias las inconsistencias textuales de carácter sustancial y accidental que alteran el sentido, enturbian su estilo poético y, desde luego, el proceso de interpretación; por tanto, como ya se informó, la edición crítica de la obra las subsanó.

\section{Fronda lírica}

La obra príncipe se publicó en Madrid (1908), Balgañón y Moreno, y la segunda edición, en Barranquilla, Colombia (1922), Tipografía Mogollón; está conformada por 16 poemas: «Altas

$\overline{22}$ Por ejemplo, en el poema «La vida» del uruguayo Julio Herrera y Reissig. 
ternuras», «Año harmónico», «Primavera», «Estío», «Otoño», «Invierno», «Fuego y ceniza», «La voz del río», «Marta», «Gloria tropical», «Fin de un drama», «El rey Febo», «Nina», «Idilio eterno», «La araña», y «Buscadores de orquídeas». Reposa en la Casa Museo Julio Flórez y en la Biblioteca Luis Ángel Arango de Bogotá con el siguiente registro: "Co 861.5 F56f1, 2. ${ }^{\mathrm{a}}$ ed. B/quilla: Tipografía Mogollón". Una vez salió a la luz la obra príncipe, Flórez obsequió un ejemplar al lingüista colombiano Rufino José Cuervo, quien respondió a esa generosidad con una carta escrita a mano; léase la versión transcrita en imprenta por Gloria Serpa-Flórez (1994, pp. 228-230):

C. de U. París, 18, rue de Siam. 8 de julio de 1908

\section{Señor D. Julio Flórez}

Pte.

Mi querido amigo:

He de confesar que con los años he perdido algo el buen gusto de los versos; pero aseguro a U. que la lectura de Fronda Lírica ha renovado la fruición que me causaban en los mejores años de mi vida. Allí aparece U. como maestro consumado que domina la lengua, así para la cabal expresión de todos sus conceptos, como para lograr los efectos más de- licados de la rítmica. La firmeza del estilo, la intensidad del sentimiento, la intuición profunda de las cosas de la naturaleza y sus relaciones, se ostentan en mayor o menor grado, con frecuencia soberanamente, en cada una de sus poesías; tal que algunas traen a la memoria obras maestras de todos admiradas.

El Año Harmónico me ha recordado las filigranas incomparables del Walpurgis clásico del segundo Fausto; El rey Febo tiene un no sé qué de la solemnidad con que Lucrecia invoca a Venus al principiar su poema; La Araña hace pensar en El Cuervo de Poe; sin que haya en ninguna imitación, y acaso ni sugestión. Sería cosa de nunca acabar si hubiera de hablar a U. de todos los méritos y primores de cada composición.

En la obra de U. ya de algunos años se nota constante ascensión. La nota amarga, destilada de sus pesares y prenda al mismo tiempo de su sinceridad, acaso se suavice también cuando llegue al fondo de su ser la sutilísima voz del místico ascende superius, y desde la cima escampada del inspirado Olimpo vea U. la armonía de todos los mundos y sienta caer sobre su corazón la paz y la dulce serenidad.

Reciba U. las más infinitas felicitaciones de su amigo y admirador

\section{R. J. Cuervo}

Como se ve, Rufino José Cuervo exaltó la calidad literaria de esta obra de Flórez, su esteticidad y la manera de abordar los distintos elementos poéticos, entre ellos, la naturaleza; comparó algunos poemas de Fronda lírica con clásicos de la literatura universal, con lo cual honró el talento del poeta. De otra parte, en uno de los álbumes familiares de Flórez, se halló la siguiente nota en manuscrito de la poetisa española Emilia Pardo Bazán: «La condesa de Pardo Bazán agradece mucho al Sr. Julio Flórez el envío de sus preciosos poemas. Son realmente muy hermosos y me gusta mucho el de "La Araña"» (Gloria Serpa-Flórez, 1994, p. 217). Léase la primera estrofa de este poema que Flórez declamó en París el 20 de julio de 1908, con motivo de la celebración de la Independencia de Colombia:

\footnotetext{
Entre las hojas de laurel marchitas de la corona vieja, que en lo alto de mi lecho suspendida,

un triunfo no alcanzado me recuerda, una araña ha formado
} 
su lóbrega vivienda, con hilos tembladores más blandos que la seda, donde aguarda a las moscas haciendo centinela, a las moscas incautas que allí prisión encuentran, y que la araña chupa con ansiedad suprema.

Varios literatos de la época comentaron que el génesis y motivo de inspiración para su creación fue el siguiente incidente, relatado por León Julio Flórez Moreno (1967) ${ }^{23}$ : el presidente de Colombia Miguel Antonio Caro organizó en Bogotá, en 1895 , un concierto de caridad que se realizaría en el Teatro Colón, y para elaborar la agenda del evento pensó en la declamación de un poema por parte del mismo Flórez, y aprovecharía para, una vez terminada la velada, obsequiarle una corona de laurel por sus triunfos literarios. Flórez aceptó participar, pero como el presidente conocía su carácter rebelde y su ideología política (contraria a la suya) solicitó el texto escrito del poema que recitaría. A esta petición, el poeta se negó, por cuanto la composición ya elegida para esa velada sería ¡Oh poetas!, poema (suelto) contestatario que incita al pueblo a reclamar justicia. Lo declamó ante los asesores del presidente, pero ellos adujeron que no sería aprobado por Caro, a lo cual Flórez contestó: "en- tonces no iré al teatro":

Cuando en el concierto llegó el número del programa que le correspondía [a Julio Flórez] y se vio que en lugar de él salía a escena un cantante y un pianista, los gritos de la galería fueron ensordecedores: ‘¡Flórez!', ‘¡Flórez!', decían arriba y en la platea: '¡Que salga Flórez!' Aquella algarabía espantosa duró diez minutos. Y si hubiera recitado los versos, muchos se habrían salido del teatro, con ánimo de tomarse los cuarteles a puñetazos o con bastones. Al día siguiente, muy temprano, varios amigos le llevaron a su cuarto la corona de laurel [...] (pp. 57-58)

«La araña» suscitó muchos comentarios en los estudiosos de la literatura tan pronto se conoció, trataron de hallar en ese poema la realidad política que angustiaba a Flórez, opiniones que provocaron el enojo del poeta. En respuesta a algunas de esas interpretaciones, escribió:

No sé por qué afirman que mi araña es una mixtificación y que yo no soy ahora sino un apacible burgués. La araña la vieron muchos compañeros míos, Valencia, entre otros, en una de las coronas que colgaban bajo mi mesa de trabajo y que se perdieron el día en que por algún asunto político me lanzaron a la calle [...] Sé bien que en el fondo no hay otra cosa que el deseo de mortificarme [...] ¿Es esto que tan cerca está de la poesía lo que da lugar a que me llamen burgués? (Serpa, 1994, pp. 126-127)

Como ya se expuso, Flórez, considerado por los estudiosos de la literatura como representante del Romanticismo tardío en Colombia, ingresa con este poema en la estética modernista-simbolista, de la cual toma varias innovaciones. Fronda lírica al igual que Horas, también contiene algunos poemas que revelan el asombro de Flórez frente a la naturaleza, fue un gran intérprete de ella; a través del encanto, los colores, los ensueños y la belleza de los paisajes tropicales colombianos simbolizó múltiples sentidos, entre ellos, el ciclo de la vida humana (en «Primavera», «Estío»e «Invierno») el amor (en «Marta»), el nacionalismo y el arraigo patrio (en «Gloria tropical»), y el valor vital del sol (en «El Rey Febo»); veamos de este poema las estrofas 2,15 y $16^{24}$ : 
¡Sagitario divino!... ¿A qué profundidades

invisibles e ignotas, desbocado nos llevas?

Padre y Señor de todas las pasadas edades, dueño de las futuras: mientras tu mole muevas, mientras brilles, iremos tras de tus claridades!

Rey del jardín sublime: cuando al cenit asciendes, con tu clámide blonda de quemadores rayos,

el amor en los nidos y en las almas enciendes;

los abriles sonríen y se enrosan los mayos,

mientras tú las diademas del rocío desprendes!

Todo a ti sube: aroma, canto, plegaria, grito!

y sin embargo, apenas eres tras del gran velo

azul, que al hombre encubre la realidad o el mito,

una chispa de oro de la fragua del cielo!

Un joyel, un diamante del tesoro infinito!

Mediante el empleo de metáforas ("Rey del jardín sublime", "Un joyel, un diamante del tesoro infinito") devela la alegría que transmite el sol y su inmensa valía para lo que puede germinar y crecer en la tierra; con el uso de la metáfora logra la agudeza de las imágenes, la musicalidad poética y la capacidad para concebir desde su imaginación una realidad. Para Fray Campo E. Claro (1967), todas las bellezas naturales encontraron visibilidad y vida en la paleta poética de Flórez:

Ya el mar enorme, encrespado, rugiente, colérico, en todo el dinamismo de su sublimidad, o bien, plácido, tranquilo, dócil, quieto dialogando con los astros; ya el cielo, iluminado con la luz de las borrascas, amenazando destruir el mundo entre rayos y truenos, o azul y acogedor como un manto, envolviendo cariñoso la tierra que hacia él tiende los penachos de sus palmeras, la cresta de sus volcanes y la nieve de sus cumbres; y el águila y el cóndor alipotentes, y las aves parleras, y la suave paloma, y las garzas níveas, le brindan sus alas para que la inspiración ascienda, al paso que las fieras embravecidas le prestan sus rugidos para que en ellos vibre lo inmenso de su potencial imaginativo. (p.165).

A propósito de ese potencial imaginativo, Santos (2014), evocando a Varela-Portas (2008), aduce que la poesía tiene la capacidad de imaginar espiritualmente, de entender lo imaginado y «remontarse a las verdades veladas por las imágenes como una intelligenza nova». (p. 53), dada la agudeza mental, perceptiva y sensorial que caracteriza a muchos de los poetas.

El análisis lingüístico-estético de Horas y de Fronda lírica abordado en la Edición critica de la obra completa mostró que Flórez aprovechó las múltiples posibilidades morfológicas, sintácticas y semánticas de la adjetivación para verter su imaginación creadora $\mathrm{y}$ construir sentido. Por ejemplo, en el nivel sintáctico predominan las siguientes construcciones adjetivales: en posición yuxtapuesta; en coordinación copulativa; en concurrencia de varios adjetivos en diversas ubicaciones frente al sustantivo, doble adjetivación; alternancia de adjetivos restrictivos y no restrictivos; adjetivos sustantivados; recategorización de adjetivos en sustantivos mediante el plural (caracterizadores de rasgos individuales de comportamiento); $\mathrm{y}$ epítetos frase, metafóricos y tipificadores (Nueva gramática de la lengua española, 2009).

Continuando con Fronda lírica, examinaremos ahora su tradición directa, así: la antología Harvard Collage Library (1912), Estados Unidos, incluyó algunos poemas de la primera edición $(1908)^{25}$; en 1922

25 Por restricción de espacio, no se indican los títulos de los poemas incluidos en cada una de las antologías. 
Flórez publicó una segunda en Barranquilla. Posteriormente apareció editada, en forma completa o parcial, en: Casa Editorial Sopena, Barcelona (1931); Ediciones Académicas, Barcelona (1943); Ediciones La Gran Colombia (1943); Ministerio de Educación Nacional de Colombia (1945); El libro español, México (1951); Publicaciones del Banco de la República, Minerva, Bogotá (1970); Ediciones Bedout, Medellín, Colombia (1983); Círculo de Lectores, Bogotá (1985); Tiempo Presente, Bogotá (1990); Editorial Panamericana, Bogotá (1997), y Academia Boyacense de Historia, Tunja, Colombia (1997).

De manera que, Fronda lírica se editó, en forma total o parcial, en los siguientes años: 1912, 1922, 1931, 1943 (dos veces), 1945, 1951, 1970, 1983, 1985,1990 y 1997 ; se observa que su tradición editorial ha sido similar a la de horas. Los poemas que mayor acogida tuvieron de los distintos editores fueron: «Primavera», «Estío», «Otoño», «Invierno», «Idilio eterno»y «La araña», vistas por los literatos como las mejores producciones de Julio Flórez, entre otras. Veamos ahora la descripción y el análisis de las variantes halladas en la transmisión editorial de Fronda lírica. Según se anunció ya, para el proceso de la collatio se eligió como texto base el apógrafo de la segunda edición, 1922 (AP) y para cotejarlo, las ediciones SO
1931 y CdL 1985, y los siete manuscritos (autógrafos):

\section{Variantes sustanciales}

Se presenta aquí dos variantes léxicas que afectan semánticamente los poemas: en "Primavera», v.28, la edición CdL cambia la lección "ampo" del AP e introduce el sustantivo "campo": "sobre el campo de su frente; frente casta", con dicha decisión se modificó el sentido del verso y de la estrofa, puesto que la intención del autor al elegir "ampo", fue connotar la inocencia de una hermosa niña que juguetea saludando la llegada de esa estación.

En el manuscrito (Ms2) y en el AP de «La voz del río», se lee "losa", v. 36, pero en las ediciones de la collatio se modifica equivocadamente y se fija el sustantivo "loza"; la primera es la lección apropiada, dado que por el sentido de esa composición, poéticamente simboliza la finitud de la vida.

\section{Variantes accidentales}

En «Otoño», v. 8, la edición SO no marca acento gráfico a *"vividas", pues el sentido del verso así lo requiere, es un adjetivo poético que alude al vigor, a la alegría, al espíritu ardiente y a la pasión en el amor; léanse estos cuatro versos como aparecen en el AP: "sus ojeras/guardan toda la ceniza/ que cayó, cuando sus ojos/ fueron vívidas hogueras"/; ese error altera el sentido del verso por el cambio semántico que genera la no marcación de la tilde. En «Fuego y ceniza», v. 82, la edición SO no tilda el relativo interrogativo *"que"; leamos el verso respectivo $\mathrm{y}$ el que le sigue, como aparecen en el AP: "No sé qué noble y vigoroso impulso/ me empujó hacia la hermosa"/, evidentemente tildándolo se aclara su sentido. En este mismo poema, la edición SO cambia sin razón el pronombre posesivo "su" por el pronombre personal átono de complemento indirecto "le", al fijar en el v. 77: "me parece aún que le respiro" en lugar de "me parece aún que su respiro", dado que así lo exige el siguiente verso que lo completa: "y que su soplo embalsamado siento", ese posesivo asegura la concordancia de los dos versos.

En «Marta», v.53, la edición SO omite la /u/ que debe ir después de la /g/ y establece erróneamente el vocablo *"extingió", este parece ser un error de digitalización. En «Buscadores de orquídeas», v. 38 , esta misma edición olvida marcar el acento gráfico al pronombre personal "Él", para que el lector logre interpretar la intención del hablante lírico de personificar el árbol derrumbado por un depredador.

En «Fuego y ceniza», v.91, la edición CdL ubica, sin justificación, una tilde en la palabra * "acába", no es recomendable ese acento gráfico, puesto que 
se trata de una palabra grave terminada en vocal. En cambio, elimina la diéresis que el poeta sitúa en "ocëanos" para conservar la métrica del v.67 en «El Rey Febo». A propósito de la construcción poética de Fronda lírica, en su AP se observa el uso del endecasílabo, pero combinado con versos de diferentes medidas y el empleo recurrente en un mismo poema de estrofas de distinta clase (dísticos, tercetos, cuartetos, quintetos, quintillas, sextinas, octavas, décimas $\mathrm{y}$ hasta de un número mayor de versos) $)^{25}$.

En fin, en su transmisión editorial Fronda lírica muestra un mayor número de variantes accidentales que sustanciales, pero que igualmente alteran el sentido. Como ya se señaló, esos cambios injustificados obedecen a la ausencia de exactitud, precisión y de respeto en los procedimientos de enmienda, fijación y publicación. Al igual que en Horas, las inconsistencias editoriales tanto sustanciales como accidentales se enmendaron en la Edición crítica de la obra completa de Flórez.

\section{Conclusiones}

Julio Flórez ha sido considerado como representante del Romanticismo tardío en Colombia; sus infortunadas circunstan- cias personales y familiares, el influjo de Víctor Hugo y de Bécquer y la violencia política que consumía al país a finales del siglo XIX e inicios del XX forjaron esa sensibilidad poética. No obstante, al conocer, leer en profundidad y preparar una edición crítica de su obra completa, también se halló una transición en su poesía en 1908 hacia la corriente modernista, a través del poema «La araña» (Fronda lírica), por cuanto al ser desterrado y luego designado en un cargo diplomático en España por el presidente Rafael Reyes Prieto, tuvo la oportunidad de compartir tertulias literarias con Rubén Darío, pionero del Modernismo, y con otros de sus seguidores, lo que sin duda influyó en la transformación estética de Flórez. Dicho brevemente, esas dos tendencias estéticas que marcaron su poesía estuvieron estrechamente vinculadas a las adversidades de su entorno familiar, al proceso convulsionado, agresivo y violento de construcción de la nación y a su postura política contestataria asumida frente al Estado colombiano.

El valor poético de Flórez se concreta en la espontaneidad para interpretar los sentimientos populares y para expresar su propia sensibilidad frente a diversos temas cósmicos $\mathrm{y}$ humanos, mediante la descrip- ción plástica de la naturaleza. Aunque incurrió en "excesos retóricos" y en la repetición léxica, su lenguaje estético logra el poder expresivo mediante el uso de las distintas formas de la adjetivación de la lengua española; además, el empleo recurrente de la metáfora configura la agudeza de las imágenes y la musicalidad poética de los versos y las estrofas. Es plausible su viraje hacia la moderación y el sosiego en aspectos relacionados con la estética poética, cuando decide adoptar algunas particularidades de la tendencia modernista-simbolista.

En relación con el análisis filológico del proceso de transmisión editorial de Horas (1893) y Fronda lírica (1908, 1922), es preciso remarcar que fueron obras muy reconocidas y, en general, bien recibidas por lectores y literatos nacionales e internacionales. La tradición editorial directa de las dos es significativa, puesto que hasta 1997 se conocen ediciones publicadas en un promedio de 12 años para cada una. En dicha tradición se observó que los poemas que mayor acogida merecieron de los distintos editores fueron: de Horas, «Idilio eterno» y de Fronda lírica, «Primavera», «Estío», «Otoño», «Invierno»y «La araña».

25 Aunque no así en «Fuego y ceniza», organizado en 113 tercetos; «La voz del río», en 14 sextinas y «El Rey Febo», en 17 quintetos. 
Desde el punto de vista ecdótico, Julio Flórez no tuvo suerte, Horas y Fronda lírica han tenido que soportar, en su proceso de transmisión, la abierta e injustificada manipulación editorial; esto ha generado, que con el transcurso del tiempo, sus textos hayan acopiado inconsistencias textuales que distorsionan el sentido y su estilo poético, lo que obviamente atenta contra cualquier proceso de interpretación y de valoración de su calidad literaria; algunos editores intervinieron para introducir variantes de carácter sustancial y accidental sin que mediara razón lingüística o es- tética alguna. En el primer caso, predominan las modificaciones léxicas, en palabras llenas: sustantivos, adjetivos calificativos, verbos y pronombres (personales, demostrativos y posesivos) y en palabras de enlace: conectores y preposiciones. En el segundo caso, son abundantes los cambios en acentuación (ausencia de acentos gráficos o ubicación de estos equivocadamente y supresión de la diéresis en las palabras en las que el poeta la marcó para efectos métricos), puntuación (la coma y el signo de admiración) y en digitalización.
Indiscutiblemente, las diversas ediciones de Horas y Fronda lírica expresan su perdurabilidad, pero también los problemas textuales en sus procesos editoriales, que se subsanaron mediante la elaboración de una primera edición crítica de toda su obra que pronto saldrá a la luz pública para ser leída e interpretada de manera segura, lo cual permitirá juzgar su valor estético. Por último, se considera que con la presente investigación filológica se rescatará del olvido una producción poética colombiana.

\section{Referencias}

Alvarado, H. (1996). Julio Flórez. Poesía escogida (3. ${ }^{a}$ ed.). Bogotá: Áncora Editores.

Avendaño, G. (2014). Edición crítica de la obra completa del poeta colombiano Julio Flórez. Tesis doctoral sustentada en la Universidad Nacional de Educación a Distancia (UNED), Madrid, España.

Barón, J. (1997). (comp.). Julio Flórez en las letras nacionales y boyacenses. Tunja: Academia Boyacense de Historia.

Bedout (1983). Julio Flórez. Poemas escogidos. Medellín: talleres de editorial Bedout.

Biblioteca Luis Ángel Arango. (1970). Julio Flórez. Obra poética. Bogotá: Publicaciones del Banco de la República, Minerva.

Blecua, A. (2012). Estudios de crítica textual. Madrid: Gredos. 
Claro, F. E. (1967). Gran lírico de la naturaleza. Boyacá a Julio Flórez. Conmemoración del centenario de su nacimiento. Torres, E. (comp.). Tunja: Gobernación de Boyacá.

Ediciones Académicas. (1943). Julio Flórez. Poesía. Barcelona: Colección Inmortal.

Ediciones Harvard Collage Library. (1912). Julio Flórez. Poesías escogidas. Brownsville, Texas: Editor Morris Gray.

Ediciones La Gran Colombia. (1943). Julio Flórez. Sus mejores versos. Bogotá.

Editorial Panamericana. (1997). Julio Flórez. Selección, Cuadernillos de Poesía. Santafé de Bogotá.

Ediciones Tiempo Presente. (1990). Julio Flórez. Antología poética, 2. a edición, colección de poesía Quinto Centenario. Bogotá: editor Gerardo Rivas Moreno.

El libro español. (1951). Julio Flórez. Sus mejores poesías. Antología. Con comentarios y Biografía por Nina sesto. México, D.F.

Estévez, Á. (1998). Edición crítica, notas, coordinación de Poesía completa y prosas de Julio Herrera $y$ Reissig, París, ALLCA XX, Colección Archivos 32; 2. ${ }^{a}$ ed., 1999. Madrid: Galaxia Gutenberg / Círculo de Lectores.

Flórez, J. (1893) Horas. Bogotá: J.J. Pérez.

Flórez, J. (1908). Fronda Lirica. Madrid: Balgañón y Moreno.

Flórez, J. (1922). Fronda Lírica (Poemas) (2a. ed.). Barranquilla: Tipografía Mogollón.

Flórez, L. J. (1967). Reseña biográfica de Flórez. Boyacá a Julio Flórez. Conmemoración del centenario de su nacimiento. Torres E. (Comp.). Tunja: Gobernación de Boyacá.

Gómez R., A. (1940). Historia de la literatura colombiana. Bogotá: Extensión Cultural de Colombia.

Grillo, M. (1985, septiembre). Julio Flórez. Revista gris. Bogotá.

Gómez R., A. (1940). Historia de la literatura colombiana. Bogotá: Extensión Cultural de Colombia.

Hernández, C. (1997). Cuadernillos de Poesía. Julio Flórez Selección. Santafé de Bogotá: Panamericana Editorial.

Lapesa, R. (1981). Introducción a los estudios literarios. Madrid: Cátedra.

Luque, O. (1931). Julio Flórez. Poesías. Barcelona: Casa Editorial Sopena. 
Martínez, A. (1973). Julio Flórez. Su vida y su obra. Introducción de Carlos Valderrama Andrade. Bogotá: Instituto Caro y Cuervo, serie la Granada Entreabierta.

Ministerio de Educación Nacional de Colombia (1945). Julio Flórez. Poesía. Bogotá: Biblioteca Popular de Cultura Colombiana.

Mercado, J. (1982). Julio Flórez o la retórica del dolor. Bogotá: colección literaria Poliforo de Oriente, Biblioteca Politécnico Colombiano.

Nieto Ruíz, L.F. (2011). El papel del lenguaje en las estrategias discursivas para fomentar la enseñanza-aprendizaje. Cuadernos de Lingüística Hispánica, (18), 135-153. Recuperado de http://revistas.uptc.edu.co/revistas/index.php/ linguistica_hispanica/article/view/438/438

Ocampo, J. (1997). Julio Flórez: el poeta popular del amor, la tristeza y la nostalgia. Julio Flórez en las letras nacionales y boyacenses. Barón O., J. (comp.).Tunja: Academia Boyacense de Historia.

Orduna, G. (2005). Fundamentos de crítica textual. Ed. de Leonardo Funes y José Manuel Lucía Megías. Madrid: editorial ARCO/LIBROS S.L.

Panero, J. (1985). Julio Flórez. Antología poética. Bogotá: Círculo de Lectores.

Peña, P. (1997). Boceto biográfico de Julio Flórez. Julio Flórez en las letras nacionales y boyacenses. Barón O., J. (comp.). Tunja: Academia Boyacense de Historia.

Pérez, M. (2011). Teoría de la literatura y literatura comparada. La edición de textos. $2 .{ }^{a}$ edición ampliada y actualizada. Madrid: Editorial Síntesis.

Ponce, S. (1893, entrega 10 de julio). Julio Flórez y sus “Horas”. Revista Gris (año I), 330-345. Bogotá.

Real Academia de la Lengua Española (2010). Ortografía de la lengua española. Madrid: Espasa.

Real Academia de la Lengua Española (2009). Nueva gramática de la lengua española. Madrid: Espasa.

Real Academia de la Lengua Española (2006). Diccionario esencial de la lengua española. Madrid: Espasa.

Real Academia de la Lengua Española (2005). Diccionario panhispánico de dudas. Madrid: Santillana.

Restrepo, H. (1972). La gran crónica de Julio Flórez. Bogotá: Instituto Colombiano de Cultura.

Rivadeneira, A. (1997). Tres visiones del poeta. Julio Flórez en las letras nacionales y boyacenses. Barón O., J. (comp.).Tunja: Academia Boyacense de Historia. 
Sanín, B. (1967). Cantor de grandes tristezas. Boyacá a Julio Flórez. Conmemoración del centenario de su nacimiento. Torres, E. (comp.).Tunja: Gobernación de Boyacá.

Santos García, E. (Enero-Junio de 2014). Anhelo Cognitivo y Muerte del Ideal en la Lírica Colombiana. La Palabra (24), 45-58. Recuperado de http://revistas.uptc.edu.co/revistas/index.php/la_palabra/article/view/2500/2359

Serpa-Flórez, G. (1994). “Todo nos llega Tarde...” Biografia del poeta colombiano Julio Flórez. Bogotá: Planeta Colombiana Editorial.

Torres, C. A. (mayo 22 de 1915). Julio Flórez. El liberal ilustrado (Tomo IV, 1), 245-247.

Ureña, H. (1967). El bardo de la "Lira Nueva”. Boyacá a Julio Flórez. Conmemoración del centenario de su nacimiento. Torres, E. (comp.). Tunja: Gobernación de Boyacá. 